\title{
The Effect of Collective Forest Tenure Reform on Farmers' Forestry Income: Evidence from Investigation Data
}

\author{
Li Huang ${ }^{1, \text { a }}$, Mi Zhou ${ }^{2, b}$ \\ ${ }^{1}$ Information Center of Liaoning Province Commission of Rural Economy, Shenyang China \\ ${ }^{2}$ College of Economics and Management; Shenyang Agricultural University, Shenyang China \\ ahuanglixxzx@163.com, bdhtzor@163.com
}

Keywords: Collective forest tenure reform; Forestry revenues; Liaoning province

\begin{abstract}
After the collective forest tenure reform, the change of farmers' forestry income has drawn much attention. Based on-the-spot investigation data, this paper analyzed the change of farmers' woodland area, woodland blocks and income before and after the reform, and then conducted a probit model to analyze the influencing factors of the effect of the collective forest tenure reform on farmers' forestry income, The results showed that the age of householder, education level of householder, whether to accept forestry technical training, and whether the farmer' woodland was given forest right certification these four factors had significant impact on the effects of the collective forest tenure reform on farmers' forestry income.
\end{abstract}

\section{Presentation of Questions}

Collective woodland was one of the most important national land resources; it was an important forestry production factor and living guarantee for farmers. As Liaoning province was the pilot province of collective forest tenure reform in northern china, it was significant to explore what factors might affect the impacts of the reform on the forest farmers' revenues. Based on-the-spot investigation data from 332 farmers in Liaoning, this article developed an empirical analysis of the influencing factors of the effect of the collective forest tenure reform on farmers' forestry income by using the probit model, and the aim of this paper was to provide scientific basis for perfecting the reform policy in the future.

\section{Sample}

We draw our data from a spot investigation implemented by Liaoning Collective Forest Tenure Reform studying team of Shenyang Agricultural University. According to different types of Liaoning collective forest tenure, different regions and different economic and social conditions, the team carried out questionnaires investigation and interview with farmers and village cadres and informal discussion with grass-roots village organizations, governments at all levels, forestry departments and forestry enterprises. The investigation combined the method of typical investigation with random investigation and was carried out a month during August 20 to September 20,2007. The range of investigation covered both east and western region of Liaoning province, which included kuandian county and fengcheng county of Dandong city, benxi county and huanren county of Benxi city, fushun county and xinbin county of Fushun city in the eastern region; zhangwu county of Fuxin city and jianping county of Chaoyang city in the western region, a total of 340 farmers in 42 villages of 21 townships (towns) of 8 counties. 


\section{Empirical analysis}

Variable declaration.

Specific descriptions of each independent variable are shown in table 1.

Table 1 Variable definition and description

\begin{tabular}{|c|c|c|}
\hline Variables & Explanation & Prior judgment \\
\hline $\mathrm{X} 1$ & age of householder (years) & positive \\
\hline $\mathrm{X} 2$ & $\begin{array}{l}\text { education level of householder (illiteracy =1; } 1-3 \text { of primary school =2; } 4-6 \text { of primary school =3; junior middle school =4; } \\
\text { high school =5; secondary or technical school =6; junior college =7; college or university and above =8) }\end{array}$ & uncertain \\
\hline X3 & whether to accept forestry technical training $(y e s=1 ; n o=0)$ & positive \\
\hline $\mathrm{X} 4$ & family labor force number (person) & uncertain \\
\hline $\mathrm{X} 5$ & whether there were cadres in family members $($ yes $=1 ;$ no $=0$ ) & positive \\
\hline $\mathrm{X} 6$ & woodland area（acres） & positive \\
\hline $\mathrm{X} 7$ & woodland block (blocks) & positive \\
\hline $\mathrm{X} 8$ & $\begin{array}{l}\text { the farthest distances from woodland to the main roads ( less than } 2000 \text { meters }=1 ; 2000-5000 \text { meters }=2 ; 5000-10000 \text { meters } \\
=3 \text {; more than } 10000 \text { meters }=4 \text { ) }\end{array}$ & positive \\
\hline X9 & the number of family members engaging in forestry production (person) & negative \\
\hline $\mathrm{X} 10$ & whether the farmers joined forestry cooperation organizations $($ yes $=1 ;$ no=0 $)$ & positive \\
\hline X11 & whether the farmer heard of collective forest tenure reform $($ yes $=1 ;$ no=0 $)$ & positive \\
\hline $\mathrm{X} 12$ & whether the farmer' woodland was given forest right certification (yes=1; no=0) & positive \\
\hline $\mathrm{X} 13$ & tern Liaoning =1; western Liaoning =2) & \\
\hline
\end{tabular}

\section{Estimation results.}

This article developed a probit model to estimate the sample data by use of stata10.0 software and the estimated results were good. The difference between the two models was that there was dummy variable in model 2. Estimated results were shown in table 2:

Table 2 Probit model estimates

\begin{tabular}{|c|c|c|c|c|c|c|c|c|c|c|}
\hline \multirow{2}{*}{ Variables } & \multicolumn{5}{|c|}{ Model 1} & \multicolumn{5}{|c|}{ Model 2} \\
\hline & coefficient & standard error & z & $\mathrm{P}>|\mathrm{z}|$ & $\mathrm{dy} / \mathrm{dx}$ & coefficient & standard error & z & $\mathrm{P}>|\mathrm{z}|$ & $\mathrm{dy} / \mathrm{dx} \mathrm{b}^{\mathrm{b}}$ \\
\hline $\mathrm{X} 1$ & 0.0168 & 0.0098 & 1.71 & 0.087 & 0.0029 & 0.0165 & 0.0099 & 1.66 & 0.097 & 0.0027 \\
\hline X2 & -0.2136 & 0.0975 & -2.19 & 0.028 & -0.0365 & -0.2317 & 0.0985 & -2.35 & 0.019 & -0.0387 \\
\hline$X 3^{a}$ & 0.9141 & 0.4707 & 1.94 & 0.052 & 0.2474 & 0.9854 & 0.4736 & 2.08 & 0.037 & 0.2696 \\
\hline $\mathrm{X} 4$ & -0.102 & 0.0888 & -1.15 & 0.251 & -0.0174 & -0.0858 & 0.0905 & -0.95 & 0.343 & -0.0143 \\
\hline$X 5^{a}$ & 0.3076 & 0.2494 & 1.23 & 0.217 & 0.0597 & 0.3106 & 0.2543 & 1.22 & 0.222 & 0.0591 \\
\hline $\mathrm{X} 6$ & 0.0002 & 0.0004 & 0.68 & 0.496 & 0.00004 & 0.0003 & 0.0003 & 0.82 & 0.415 & 0.00005 \\
\hline $\mathrm{X} 7$ & 0.0558 & 0.0953 & 0.59 & 0.558 & 0.0095 & 0.051 & 0.0954 & 0.54 & 0.593 & 0.0085 \\
\hline X8 & -0.1666 & 0.1101 & -1.51 & 0.130 & -0.0285 & -0.1625 & 0.1118 & -1.45 & 0.146 & -0.0271 \\
\hline X9 & 0.055 & 0.1046 & 0.53 & 0.599 & 0.0094 & 0.0843 & 0.1055 & 0.80 & 0.424 & 0.0141 \\
\hline $\mathrm{X} 10^{\mathrm{a}}$ & 0.2587 & 0.3296 & 0.78 & 0.433 & 0.0508 & 0.3343 & 0.333 & 1.00 & 0.315 & 0.0667 \\
\hline $\mathrm{X} 12^{\mathrm{a}}$ & 0.4284 & 0.2145 & 2.00 & 0.046 & 0.0845 & 0.4216 & 0.2169 & 1.94 & 0.052 & 0.0812 \\
\hline $\mathrm{X} 13$ & -- & -- & -- & -- & -- & 0.7175 & 0.3554 & 2.02 & 0.043 & 0.1197 \\
\hline C & -1.1208 & 0.7367 & -1.52 & 0.128 & -- & -1.8874 & 0.8297 & -2.27 & 0.023 & -- \\
\hline \multicolumn{6}{|c|}{ Log likelihood=-103.2443 } & \multicolumn{5}{|c|}{ Log likelihood=-101.3195 } \\
\hline \multicolumn{6}{|c|}{ Prob $>$ chi $2=0.01$} & \multicolumn{5}{|c|}{ Prob $>$ chi2 $2=0.00$} \\
\hline \multicolumn{6}{|c|}{ Pseudo R2=0.099 } & \multicolumn{5}{|c|}{ Pseudo R2 $=0.1159$} \\
\hline
\end{tabular}




\section{Estimation results}

We can conclude from the estimated results of model 2 that, age of householder, education level of householder, whether to accept forestry technical training, and whether the farmer' woodland was given forest right certification these four factors had significant effects on dependent variable, and the factor education level of householder had a negative effect on the dependent variable, while the effect directions of the other three factors was consistent with the estimated directions; family labor force number, whether there were cadres in family members, woodland area, woodland block, the farthest distances from woodland to the main roads, the number of family members engaging in forestry production and whether the farmers joined forestry cooperation organizations, these factors had significant effects on dependent variable, among which family labor force number had a negative effect on the dependent variable, while the effect directions of the remaining factors was consistent with the estimated directions.

(1) Age of householder had a positive influence on the effect of the reform on farmers' forestry revenue. The older the householder was, the greater the possibility of the reform' effect on farmers' forestry revenue was, and the marginal effect results revealed that under the conditions of all other variables remaining unchanged, each additional 1 year of the householder's age, the average increment of the probability of the reform having an impact on farmers' forestry revenue was $0.27 \%$.

(2) Education level of householder had a negative influence on the effect of the reform on farmers' forestry revenue. The lower the education level of householder was, the greater the possibility of the reform' effect on farmers' forestry revenue was, and the marginal effect results revealed that under the conditions of all other variables remaining unchanged, each additional rising of education level of the householder's age, the average reduction of the probability of the reform having an impact on farmers' forestry revenue was 0.039 .

(3) Whether to accept forestry technical training had a positive influence on the effect of the reform on farmers' forestry revenue. If the farmer had accepted forestry technical training, then the average increment of the probability of the reform having an impact on farmers' forestry revenue was 0.27 .

(4) Whether the farmer' woodland was given forest right certification had a positive influence on the effect of the reform on farmers' forestry revenue. If the woodland was given forest right certification, then the average increment of the probability of the reform having an impact on farmers’ forestry revenue was 0.081 .

\section{Research findings}

The sample data was collected two years after the implementation of the reform, so only a short-term evaluation of the actual impact of the reform could be carried out. Through the descriptive analysis of the sample data, we found that Liaoning collective forest tenure reform had no significant influence on farmers' in sample areas and even more tiny effects on farmers' actual forestry income. However, farmers' woodland area and woodland blocks increased significantly after the implementation of the reform, with an increase of nearly $55 \%$ in woodland areas and an increase of nearly $47 \%$ in woodland blocks. Generally, if woodland area increased, the expected income from operating woodland may increase, so forest farmers will have a more active enthusiasm in operating woodland, and then their actual forestry income may improve; while the increase of woodland blocks showed a more decentralized woodland, which was not conducive to large-scale management of woodland and may affect the expected return of forest woodland. 
However, from the estimation results, we knew that woodland blocks had a positive impact on the influence of the reform on farmers' forestry revenue.

This paper developed an empirical model to analyze the influencing factors of the reform on farmers' forestry income and the results showed that, whether to accept forestry technical training and whether the farmer' woodland was given forest right certification were two important external factors. There were few farmers who had accepted forestry technical training in the sample area, while the technology of forest cultivation, pest control and understory diversified economy were very important for improving farmers' forestry income; there were 78 farmers' woodland in the sample area were given forest right certifications, accounting for $23.49 \%$ of the total sample, which was a very small proportion. One of the main reasons why the forest right certifications were not granted is that many certifications were in the process of handling or making, thus were not given to farmers, and the number of this kind farmers were 212 , accounting for $63.86 \%$ of the total households. The forest right certification can guarantee the right of farmers to operate the mountain forest, so farmers could be at ease about forest investment and production only when they really got the forest right certification in their hands.

\section{Acknowledgements}

Mi Zhou is a corresponding author. This work was supported by the National Science Foundation of China(NO.71203146; NO.71273179; NO.71373163; NO.71273177), the program for excellent talents in Liaoning province (NO.WJQ2014016); and agriculture youth science and technology innovation talent training plan in Liaoning province (NO.2014055).

\section{Reference}

Li Zhou. Evaluation and Thinking on Forestry Tenure Reform[J]. Forestry Economics, 2008 (9):3-8.

Zhang Haipeng, Xu Jintao.Collective Forest Tenure Reform:Assessment of Motivation,Characteristics and Performance[J]. Scientia Silvae Sinicae,2009 (7):119-125

Li Ya, Jiang Chunqian. Analysis of the effect of Forestry Tenure Reform and farmers' willingness in collective forest area of Jiangxi Province: A Case Study on yongfeng, shangyuan and longgui village in Jiangxi Province[J]. Chinese Rural Economy, 2007 (12):54-61.

Xu Jintao, Sun Yan, Jiang Xuemei and Li Jie. Collective Forest Tenure Reform in China:Analysis of Pattern and Performance[J]. Forestry Economics, 2008 (9):27-38.

Kong Fanbin. Theorical and Empirical Research of Performance Evaluation for the Policy of Collective Forestry Property Rights System Reform[J]. Scientia Silvae Sinicae, 2008 (10):132-141. Zhang Lei, Wen Caiyun. Impacts of Collective Forest Tenure Reform on Farmer Households' Livelihoo: An Empirical Analysis Based on Jiangxi,Fujian,Liaoning and Yunnan Provinces[J]. Scientia Silvae Sinicae, 2008 (7):73-78.

Zheng Shengwen. Evaluation of Effect of the Forest Ownership's Reform on Sustainable Development[D].2006.4

Ning Manxiu, Xing Li and Zhong Funing. Factors Influencing Farmers’ Decisions to Purchase Crop Insurance: A Case Study on Manas Valley, Xinjiang[J].Problem of Agricultural Economy, 2005(6):38-43. 